\title{
LETTERS FROM CHARLES LYELL AND ADAM SEDGWIGK TO H. B. TRISTRAM
}

\section{By S. I. TomkeIEFF}

Some years ago in Durham city, I bought a copy of the ninth edition of Lyell's Principles of Geology (1853). At the back of the front cover it bore the ex libris of H. B. Tristram and an inscription stating that the book was presented to H. B. Tristram by the East Durham Book Hawking Society. Between the pages of this book I found three letters addressed to H. B. Tristram-two from Lyell and one from Sedgwick. These letters, as far as I know, have never been published. The name of Tristram does not occur in Life, letters and journals of Sir Charles Lyell, ${ }^{2}$ books on Lyell by T. G. Bonney ${ }^{3}$ and E. Bailey, ${ }^{4}$ and in Life and letters of Sedgwick. ${ }^{5}$ Thus the publication of these letters may be of historical interest. I have consulted Lord Lyell and his mother, Lady Lyell, who have no objection to the letters being published, but I failed to get in touch with the descendants of H. B. Tristram, or Sedgwick. The three letters contain no private matter and their publication can offend no one.

The Reverend Henry Bower Tristram (1822-I906), divine and naturalist, obtained his B.A. and M.A. at Oxford, in 1849 he became Rector at Castle Eden, Co. Durham, and in 1870 Canon of Durham Cathedral. In I855-1857 he travelled in Algeria, the Sahara and later in Palestine and Egypt. In 1860 he published a book, The Great Sahara. Apparently Tristram was interested in the geomorphology, geology and botany of these countries and was in touch with a number of naturalists of this period.

As has been shown by Bodenheimer, ${ }^{6}$ Tristram was a great collector of animals, birds, insects and plants.

Here are copies of the three letters addressed to Canon Tristram:

'Dear Sir,

53 Harley Street, London W.

'I beg you to accept my best thanks for a copy of your work the Great Sahara which Mr. Murray showed me in MS. and which I hope and expect will be successful. I am reading it with great interest.

'Believe me,

truly yours
Cha Lyell'

(Dated: I6 January I86 I.)

1 Charles Lyell, Principles of Geology, gth edn., London, 1853 .

${ }^{2}$ Lyell (Mrs.), Life, Letters and Journals of Sir Charles Lyell, London, 1881.

3 T. G. Bonney, Charles Lyell and Modern Geology, London, 1895.

4 E. Bailey, Charles Lyell, London, 1962.

$5 \mathrm{~J}$. W. Clark and T. M. Hughes, The Life and Letters of the Reverend Adam Sedgwick, Cambridge, 1890.

6 F. S. Bodenheimer, 'H. B. Tristram's Collections in Natural History, especially of Palestine', Annals of Science, xii (1956), 278. 
'Dear Sir,

53 Harley Street, London W.

'It has occurred to me since I published my work on The Geological Evidences of the Antiquity of $\mathrm{Man}^{7}$ that I ought in speculating on the changes of climate and on the former extension of the Alpine Glaciers to have adverted particularly to a cause on which I have often reflected but which I wholly forgot when writing my book. I mean the fact that a large part of the Sahara from the hot sands of which the Sirocco blows was the bed of a post-Pliocene sea, and therefore the glaciers of the Alps were not checked in their growth as they are now by those hot winds from the south.

'I well remember in 1829 in Oct. or Nov. that in 24 hours all the snows of Etna were melted by the Sirocco although my guide had told me that the snow would last all the winter and that I had no chance of ascending to the summit that year.

'I think I have seen somewhere in the French Bulletin de la Société Géologique some account of recent shells Cardium edule among others strewed over the desert or in superficial formations. evidence.

'I have your book and you refer to this subject but not I think to shell

'If I knew how many days in the year the Sirocco blows it would help me or if your reading suggests to you any hints to me on the subject you would greatly oblige me by references.

'Some parts of the Sahara are below the Mediterranean. Are any of the sandy portions more than 400 or 500 feet above its level?

'Excuse my asking you so many questions and believe me truly yours

Cha Lyell'

(Dated: 6 July 1863.)

‘Sir

Aldeborough.

'With a feeling of shame and sorrow I have found a letter of yours, written last autumn in my unanswered packet. I trust that it may have been answered by my assistant in the Cambridge Museum. Should this not be the case, I can only plead as my apology the infirmity and obliviousness of old age. Since I past my 8Ist birthday I have met with a succession of domestic sorrows which have greatly shaken my health. During the latter part of winter and the early part of spring the condition of my eyes prevented me from writing except by help of an amanuensis. And since my eyes partially recovered I have been tormented by such frequent attacks of vertigo that for the past two months I have been ordered by my Physician to abstain from all study and neither to write nor dictate letters. Thank God I am much better; and for the last week I have been communicating with some of my correspondents. I am too poor to purchase any part of your collection. Yet it would be a most interesting addition to our Museum, which is rich is rich [sic] in the Cretaceous Series of England-and especially in the Chalk fishes. It would be deeply interesting to compare the typical fishes from the chalk formations of Palestine with those of our Island-But alas! I have been taxing the University funds past endurance; and I have not long since exhausted my own purse by a large collection of the Oxford Clay Reptiles which I have placed in the University Museum.

7 Charles Lyell, The Geological Evidence of the Antiquity of Man, London, I863. 
I am, spite of apparent neglect, truly grateful to you for your kind letter, and remain with all good Christian wishes

very faithfully and gratefully yours

A Sedgwick

P.S. I am in a few hours about to leave this quiet old town; and in a few days hope to be again in Cambridge.'

(Dated: 20 June 1866. )

Lyell's letter of 16 January $\mathrm{I} 86 \mathrm{I}$ is unaccompanied by an envelope. Apparently John Murray, Lyell's publisher, had shown the Manuscript of Tristram's book to Lyell and the letter is the acknowledgement of the received copy of the book.

The second letter of Lyell, 6 July 1863 , is enclosed in the original envelope, addressed to Revd. H. B. Tristram, Castle Eden, Durham (crossed out) Greatham, Stockton on Tees, substituted. The two stamp cancellations are 8 July 63 and Ferry Hill, 9 July 63 .

This letter refers to matters of great geological interest. In February I 863 Lyell's book on the Antiquity of Man was published. Some critics called this book a trilogy: 'Man-Ice-Darwin', discussing the evolution of man in the background of changing climate. Lyell's letter is thus a valuable contribution to the historical development of the problem of the influence of climate on the evolution of man.

Sedgwick's letter of 20 June I 866 is enclosed in an envelope addressed to the Revd. H. B. Tristram, Greatham Rectory, Stockton upon Tees, and bearing the cancellation mark: Saxmundham, 20 June 66 .

The envelope and the first page of the letter have a black border, no doubt in memory of Sedgwick's brother James (I 794-I 866). During the year I 866 Sedgwick lost many friends and himself suffered from the debility of old age-he was 8I years old-and from ill health, as the letter shows. In spite of all this, at the end of October I 866 he began his course of lectures on geology in the University of Cambridge. Sedgwick's letter to Tristram is concerned with the collection of fossils from Palestine which Tristram offered to sell to Cambridge University Museum. The letter is rather pathetic as written by an old man full of sorrows, and in it we see lapsus linguae, such as the repetition 'is rich is rich'. It is interesting to note that Sedgwick had spent his private income on a collection for the university museum.

Charles Lyell (I 797-1875) and Adam Sedgwick (1785-1873) both died in the decade following the letters written to the Rev. Tristram. 